\title{
Beowulf 33a and Hapax Legomena
}

\author{
Patrick Stiles $^{1}$ (D)
}

Published online: 20 August 2019

(c) The Author(s) 2019

\begin{abstract}
It is pointed out that $\bar{u} t f \bar{u} s$ in line 33a of the Old English poem Beowulf is not a hapax legomenon, as it appears in two late Middle English verse texts. It is also argued that the first word of the half line, manuscript $\bar{\imath} s i \dot{g}$, is a hapax legomenon in English, if emendation to $\bar{l} l i g$ is accepted. The distribution of this latter adjective in West Germanic and its meaning are discussed.
\end{abstract}

Keywords Old English · Beowulf · Hapax legomena · OE ütfūs $\cdot$ ME outfous · OE $\bar{\imath}$ sigh/lig · German eilig

\section{ütfüs is not a hapax legomenon}

The unnumbered prologue of the Old English epic poem Beowulf contains a description of the burial at sea of Scyld Scefing, legendary ancestor of the Danish kings. The ship that will bear him away waits ready at the water's edge,

\section{$\bar{\imath} \operatorname{sig}$ ond $\bar{u} t f \bar{u} s$}

—as the text reads in the fourth edition of Klaeber's Beowulf, line 33a (Fulk et al. 2008: 4). In that work's Glossary, ütfūs "eager (to be) out", although a transparent formation, ${ }^{1}$ is marked with a double obelos, indicating that the editors consider it to be a word 'not elsewhere found in poetry (or prose)' (2008: 343). If one confines oneself to Old English, this statement is true. However, the word was discovered in

\footnotetext{
1 Note Beowulf 755 hin-füs, 2420 wal-füs and other -füs compounds in Old English and Old Norse (-fúss). It may be noted that Norse attests no corresponding compound, which means the Middle English data about to be cited can hardly be adopted from there.

Old English, like Modern German, had the facility to create compound nouns more or less at will, so one should not necessarily attach significance to unparallelled but transparent compounds (cf. Girvan 1935: 4-7).
}

Patrick Stiles

pvstiles@yahoo.co.uk

1 University College London, London, UK 
the early 1970s in two late Middle English verse texts, in both cases as rime word with house.

In 1972, McIntosh reported outfous in two manuscripts of the late Middle English Northern Homily Cycle (or Collection), originally in the dialect of Yorkshire. There, spelled outfowse, respectively outefouse, it is used of a lapsed nun eager to go out courting (London, Lambeth 260, fol. 60r col. 2 lines 51-52 For myght scho noght stop in howse/Sa was scho walkand \& outfowse). The relevant phrase is glossed by McIntosh as "fidgety and raring to go" (1972: 202). Lambeth 260 is localized to the East Riding of Yorkshire ( $L A L M E$ I $118 \mathrm{col}$. 1), while the other manuscript to attest it, Huntington Library 129, is an Irish production (LALME I 92 col. 1): fol. 185r line 19 outefouse. That outfous is found in these two geographically dispersed witnesses suggests it was authorial. By contrast, the Vernon Manuscript (Oxford, Bodleian Library, Eng. Poet a. 1), for example - which has put the text of the Northern Homily Cycle into a West Midland dialect (LALME I 148 col. 3 assigns it to Worcestershire)-reads: ffor heo ne mihte wel reste in hous, /heo was so walkynge and so fous (ed. Horstmann 1877: 307/29-30). The fous would appear to be a reflection of the presumed original outfous in a dialect that does not know the compound.

The word was also found by Burton in several manuscripts (and one printed text of c. 1530) of the late Middle English verse dialogue Sidrak and Bokkus, there used of people who do not wish to be part of the Church, and glossed by him as "desirous to stay out or be dissociated from", although "eager to be outside" might serve (1973: 371-372). Thus, Oxford, Bodleian Library, Laud Misc. 559, fol. 147r line 27 reads: And all po pat ben outfous,/And ben spered oute of pat hous,/In payne of helle shull be shente "And all those that are eager to be outside,/And have been barred from that house [the Church],/Will be destroyed in the punishment of hell". ${ }^{2}$ The version in British Library, Lansdowne 793 reads for the first two lines: And alle pat ben shitte out of pat hous/Pat is callid Cristes spous "And all those who have been excluded from that house/that is called Christ's spouse". These two manuscripts were not included in LALME, but Burton prints Linguistic Profiles of them in his edition (Burton et al. 1998-1999: 847-864), although without drawing any conclusions. Of the other manuscripts attesting outfous, only British Library, Sloane 2232 is treated in LALME, where it is assigned to Nottinghamshire (Hand C, I 116 col. 1).

In each text, the variant versions look like a facilior lectio. The admittedly thin evidence gives the impression that in late Middle English outfous was a north(-east) Midlands and northern word. However, even if drawing such a conclusion is justified, it did not necessarily apply to early Old English, when Beowulf was composed.

If the word is found in two Middle English texts, ${ }^{3}$ it cannot be classed as a hapax legomenon for English as a whole.

\footnotetext{
2 The passage is on page 676 of his edition of 1998-1999; the Lansdowne version on page 677. There, Burton retreats from his position of 1973, suggesting as an alternative that out fous might be two words "chased out, i.e. excommunicated", with fous "an apocopated form of the p.p. of fusen in the sense "banished"' (839). This analysis seems unlikely and is the result of a desire to make different versions agree and directly reflect the French original.

${ }^{3}$ Until I contacted the editors, the Middle English Dictionary cited only the Northern Homily example, but the online Compendium now has both.
} 


\section{isig, when emended to ïlig, would be a hapax legomenon in English}

The first word in Beowulf line 33a, however, probably is a hapax legomenon in English, but only when emended to $\bar{l} l i \dot{g}$. The emendation was suggested by Alastair Campbell (in lectures) and reported by Howlett (1994: 77, repeated 1997: 509) and warmly received by Orchard (2003: 54-55), in whose forthcoming Beowulf edition it will no doubt feature. For some reason, the conjecture is not mentioned in Klaeber $4,{ }^{4}$ but it is listed in the Dictionary of Old English under the headword $\bar{l}$ sig.

As recounted by Howlett, 'Campbell noted the apparent oddity of the adjective isig in line 33 and suggested that *ilig "speedy", cognate with Old High German ilig, Modern High German eilig, would give better sense' (1994: 77). ${ }^{5}$ The balanced diction in the passage leads one to expect a word of the same general meaning as $\bar{u} t f \bar{u} s$. Howlett has identified very precise structural patterning that no less than demands such a word. It may be true that <isig $>$ is what stands in the manuscript, but that does not set a limit to knowledge. The presence of a word in the archetype that was rare-or was subsequently lost—could help account for a corruption and would certainly meet the condition of being the difficilior lectio. Replacement at some stage in the transmission of $<\mathrm{l}>$ by long $s<\lceil>$, as found in the manuscript, would be a simple scribal error, as Howlett remarks. Alternatively, it could be a case of substituting a familiar word for an unfamiliar one of similar shape (cf. Neidorf 2017: 62-68, 100-109).

Howlett-presumably, following Campbell—translates īlig as "speedy", but perhaps a better rendering here is "striving, straining". Compare the definition of OHG $\bar{l} l \bar{l} g$ in Schützeichel's dictionary: "eilig, schnell; eifrig, strebsam" (2006 s.v.; cf. Althochdeutsches Wörterbuch s.v.). For the related class I weak verb īlen, AhdWb gives as sense 3 "bestrebt sein etw[as]. (eilig, eifrig) zu tun, sich bemühen (um), trachten, streben (nach)". Kluge-Seebold (2011) s.v. eilen suggest the original meaning was "sich mühen, anstrengen"). ${ }^{6}$ In the context of Beowulf 33a, it is interesting to note that in one gloss OHG $\bar{l} l \bar{l} g$ is used of a ship: nom. sg. f. $\bar{l} l \bar{\imath} g i u$, rendering Latin AEMULA "vying" (Althochdeutsche Glossen II 707, 60, Virgil Glosses, Aeneid 5, 187 partem rostro premit aemula Pristis "vying Pristis [a sea-monster, name of a

\footnotetext{
${ }^{4}$ Neither is my defence of emendation of weaxan to weasan "to consume" in line 3115a (Stiles 2004).

5 In the context, the word "icy" seems unlikely in the extreme. However, one cannot but marvel at commentators' ingenuity in justifying the reading and their sense of 'the poetic'. In a note of 1903, Holthausen had rightly observed: 'wenn das schiff mit eis bedeckt war, musste es doch winter sein, und davon ist in der ganzen stelle (v. 26-52) keine rede. Es ist auch offenbar für die erzählung höchst gleichgiltig, zu welcher jahreszeit Scyld starb und zu schiffe den winden und wellen preisgegeben wurde!' Yet by the time of his edition published shortly afterwards, he had overcome his misgivings, contenting himself with the remark: 'Es war also Winter.' (1905-06: II 203). One thing we probably can surmise about the weather is that there was enough breeze to set the ship on its way.

6 The High German adjective is derived from the strong feminine noun $\bar{l}$ la (G Eile). Whether this in turn derives from the class I weak verb ïl(l)en (G eilen) as a postverbal noun (so Deutsches Wörterbuch Neubearbeitung 7: 456) or is the derivational basis of the verb is uncertain. For further suggestions, see Riecke 1996: 388; EWA s.v. îlen and also footnote 8 here. On the geminate -ll-, see Braune-Heidermanns 2018: §359 A1. Further derivatives in Old High German include the strong feminine nouns $\bar{l} l u n g a$ "Eile, Eilfertigkeit; Eifer; Streben" and $̄ l i g i$ "Fleiß”, to cite Schützeichel's definitions.
} 
ship] presses a part [of the ship she is racing] with her prow"). As a parallel, compare Robinson's remarks on the use of (simplex) fūs 'to modify personified inanimate objects' (1970: 109). So one could translate the Beowulf half-line: "straining and eager to depart". 7

Some might consider High German, at the far end of the West Germanic dialect continuum, too distant to justify positing the adjective for English. The noun, OHG $\bar{l} l a$, and the verb are better attested in the West Germanic languages than the adjective, which is somewhat elusive. Even in High German, where it is best represented, the Deutsches Wörterbuch Neubearbeitung (7: 454-455, s.v. EILIG) speaks of a 'bezeugungslücke zwischen dem 12. und 16. jh.'.

Old Saxon, which probably was adjacent to English as well as High German in the early West Germanic dialect continuum, does not attest the adjective (apparent examples are High German), but it has the class I weak verb (ilian*, two imperative forms only), while the noun (īle) is recorded from Middle Low German times. The adjective itself is well attested in Middle Low German, ilich "eilig, schnell" (Lasch-Borchling-Cordes 1956-s.v.), and in Modern Low German dialects, ìlig, illig "eilig, in Eile" (e.g. Stellmacher et al. 1965-s.v). It is possible that it is a loan from High German to the south, yet there is no pressing reason to posit one, and, on methodological grounds, linguistic continuity should be assumed unless there is a strong reason not to do so.

There is no sign of the adjective in Dutch, where the equivalent of German eilig in the modern standard language is haastig and the concept expressed by German es eilig haben "to be in a hurry" is realized as haast hebben, using the related noun. The verb is found once in Old Dutch in the Wachtendock Psalter gloss. This is an Old Low Frankish reworking of a south Middle Frankish - that is High Germanoriginal, the Dutch version presumed to date from the tenth century, but only surviving fragmentarily in later copies. Psalm 69.2 reads: herro te helponi mi ilo (glossing FESTINA) "O Lord, make haste to help me!", attesting an imperative singular that is a class II weak form. The verb is attested in later stages of the language. The noun is recorded since Middle Dutch, ile (cf. Franck-van Wijk 1912: s.v. ijl), but seems never to have established itself and is decidedly literary in contemporary Dutch, occurring mainly in the phrase in aller ijl "in great haste". In modern Dutch, the verb ijlen is found in eastern dialects, whether as a loan or an indigenous form reinforced by the adjacent German-speaking areas is hard to say. Its correspondent in western dialects is haasten. (Dutch also has the adverb ijlings 'in haste' (archaic and literary) from the present participle of the verb.)

No cognate is found in Old Frisian, a fact that could be taken as significant for English, as the two languages are close relatives. However, the Old Frisian corpus,

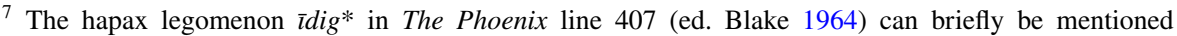
here: Wurdon teonlice topas idge "(Their) teeth were shamefully ?busy" (taking the line as a sentence for itself). I doubt that it is another disguised instance of $\bar{l}$ lig, even though it is in the correct semantic sphere. An argument against corruption of $\bar{l}$ lig is the likely etymological connection with the family of ON ið "work, activity", including Modern Norwegian, Danish and Swedish dialectal idig, idug, early Modern Standard Swedish idog "hard-working". See Blake's note and the Dictionary of Old English entry for $\bar{l}$ dig.
} 
apart from being attested relatively late, is limited both in terms of extent and subject matter, consisting almost exclusively of legal texts. Modern West Frisian parallels Dutch in lacking the adjective. Although it occurs in Modern North Frisian dialects, it can be identified in at least some as a loan(-form) from (Low) German on phonological grounds (cf. e.g. Löfstedt 1931: 158), although it could be inherited in others. The attested words for "be in a hurry" in the North Frisian dialects are relatively late borrowings (cf. Århammar 1986), leaving open the question of 'the original term'. However, in the archaic Modern East Frisian dialects, the adjective is found beside the noun: Saterlandic ielig, Wangeroogic iiliig "eilig" and Saterl. Iele, Wang. iil, (cf. Remmers 1993: 72). The adjective may well be indigenous-especially as the adjacent non-Frisian areas are characterized by the relatively recent Dutch import drock and reflexes of Low German hil(de) (Foerste 1958: 71 and Map 25). These modern East Frisian examples bring the word much closer to English and also make it more likely it was a Proto-West-Germanic term.

Whatever the interpretation of the material of the other West Germanic languages, where in any case there might have been at least semantic influence from later High German, it can be sufficient for a word to be posited for Proto-West-Germanic if it is attested in Old English and Old High German alone (provided borrowing can be ruled out). It is surely also significant that the proposed Beowulf example would agree semantically with what has been considered the original meaning of the High German term: "striving, straining". 8

If the word was Proto-West-Germanic, it must have existed in the prehistory of English. The only question would be when it died out. The conjecture makes excellent sense and is entirely fitting, while Old High German $\bar{l} l \bar{l} g$ provides an exact formal and semantic match to the proposed Old English adjective. What is more, Beowulf is characterized by much archaic vocabulary (cf. Fulk et al. 2008: cxii, clii; Neidorf 2017: 5-6, 33-34, 148-49, with references). I suggest the word should be accepted into the text and the lexicon of Old English, with appropriate signalling that it is a conjecture.

So, the net effect of these deliberations is to delete one supposed hapax legomenon and to propose another. ${ }^{9}$

Open Access This article is distributed under the terms of the Creative Commons Attribution 4.0 International License (http://creativecommons.org/licenses/by/4.0/), which permits unrestricted use, distribution,

\footnotetext{
${ }^{8}$ It is possible the word is related to such forms as the $a$-stem neuter noun OWN él "storm, shower (of rain, hail, snow)", OSw $\bar{l} l$ and $\bar{x} l$ "gust of wind, squall", Nw iling "squall", if the original idea was a surging or a straining of the air. This is hinted by Hellqvist (1948): 401 s.v. 1. il ("i s[ynner]h[e]t i förening med blåst' "especially in combination with wind"). The word would show an analogous development of long $\bar{l}$ to $\bar{e}_{2}$ before a grave liquid as seen before $r$, cf. Kuhn (1963: 271), Ringe (1984). In terms of word-formation, the class I weak verb would be denominative and this would certainly make OHG ila (etc.) a postverbal noun (cf. footnote 6).

I am dubious of the customary connection of eilen with the PIE root * $x_{1} e y$ - "to go". What is the role of the $-l-$ ? And, if the original meaning was "to strain, to strive" (cf. §4), the semantics are skewed.

9 I would like to thank the following for their help on various points: Michael Benskin, Volkert Faltings, Jan Goossens, Susan Irvine, Thomas Klein and Neophilologus' anonymous reviewers.
} 
and reproduction in any medium, provided you give appropriate credit to the original author(s) and the source, provide a link to the Creative Commons license, and indicate if changes were made.

\section{References}

AhdGl=Althochdeutsche Glossen, Die. (1879-1922). ed. Elias Steinmeyer and Eduard Sievers. 5 vols. Berlin: Weidmann.

AhdWb $=$ Althochdeutsches Wörterbuch. (1952-). ed. E. Karg-Gasterstädt, Th. Frings et al. Berlin: Akademie-Verlag.

Århammar, N. (1986). Etymologisches um den "Streß"'. In H. L. Cox, et al. (Eds.), Wortes Anst/Verbi Gratia: Donum Natalicium Gilbert. A. R. de Smet (pp. 19-28). Leuven-Amersfoort: Acco.

Blake, N. F. (Ed.). (1964). The Phoenix. Manchester: University Press.

Braune, W., \& Heidermanns, F. (2018). Althochdeutsche Grammatik I. Laut- und Formenlehre (16th ed.). Berlin: De Gruyter.

Burton, T. L. (1973). Fifteenth- and sixteenth-century antedatings, postdatings and additions to O.E.D., M.E.D. and D.O.S.T. from "Sidrak and Bokkus". Notes and Queries, 218, 369-375.

Burton, T. L. et al. (1998-99). ed. Sidrak and Bokkus. (Early English Text Society o.s. 311, 312). Oxford: Published for the Early English Text Society by the Oxford University Press.

Deutsches Wörterbuch von Jacob Grimm und Wilhelm Grimm. Neubearbeitung. ([1965-] 1983-). Stuttgart-Leipzig: S. Hirzel.

Dictionary of Old English. (1986-). Toronto: University of Toronto. Online.

EWA =Etymologisches Wörterbuch des Althochdeutschen. (1988-). ed. Lloyd, Albert L., Otto Springer and Rosemarie Lühr (Unter Mitw. von Karen K. Purdy und Gerlinde Kohlrusch). Göttingen: Vandenhoeck und Ruprecht.

Foerste, W. (1958). Der wortgeographische Aufbau des Westfälischen. In Der Raum Westfalen. IV/1. Münster i.W: Aschendorff.

Franck, J., \& van Wijk, N. (1912). Franck's etymologisch woordenboek der Nederlandsche taal. 2nd edn by N. van Wijk (1912). Reissued in 1949 together with the 1936 Supplement by C. B. van Haeringen. The Hague: Martinus Nijhoff.

Fulk, R. D., Bjork, R. E., \& Niles, J. D. (Eds.). (2008). Klaeber's Beowulf (4th ed.). Toronto: University of Toronto Press.

Girvan, R. (1935). Beowulf and the seventh century: Language and content. London: Methuen.

Hellquist, E. (1948). Svensk etymologisk ordbok (3rd ed., Vol. 2). Lund: C.W.K. Gleerup.

Holthausen, F. (1903). Zum Beowulf (v. 33). Anglia Beiblatt, 14, 82-83.

Holthausen, F. (Ed.). (1905-1906). Beowulf nebst dem Finnsburg-Bruchstück. I. Teil: Texte und Namenverzeichnis. (1905). II. Teil: Einleitung, Glossar und Anmerkungen. Heidelberg: Carl Winter.

Horstmann, C. (1877). Die Evangelien-Geschichten der Homiliensammlung des Ms. Vernon. Archiv für das Studium der Neueren Sprachen und Literaturen, 57, 241-316.

Howlett, D. R. (1994). New criteria for editing Beowulf. In D. G. Scragg \& P. E. Szarmach (Eds.), The editing of Old English (pp. 69-84). Cambridge: D.S Brewer.

Howlett, D. R. (1997). British books in biblical style. Dublin: Four Courts.

Kluge, F., \& Seebold, E. (2011). Etymologisches Wörterbuch der deutschen Sprache (25th ed.). Berlin: De Gruyter.

Kuhn, H. (1963). Der Name der Friesen. It Beaken, 25, 270-279.

LALME = A Linguistic Atlas of Late Mediaeval English. (1986). Angus McIntosh, M.L. Samuels, Michael Benskin, with the assistance of Margaret Laing and Keith Williamson. Four volumes. Aberdeen: Aberdeen University Press.

Lasch, A., Borchling, C., \& Cordes, G. (1928-). Mittelniederdeutsches Handwörterbuch. Hamburg, then Neumünster (etc.): Karl Wachholtz.

Löfstedt, E. (1931). Nordfriesische Dialektstudien. (=Die nordfriesische Mundart des Dorfes Ockholm und der Halligen II.) Lund: C.W.K. Gleerup-Leipzig: Otto Harrassowitz.

McIntosh, A. (1972). Some words in the Northern Homily Collection. Neuphilologische Mitteilungen, 73, 196-208.

Middle English Dictionary. (1952-2001). Ann Arbor: University of Michigan. Also online. 
Neidorf, L. (2017). The transmission of Beowulf. Language, culture and scribal behavior. Ithaca: Cornell University Press.

Orchard, Andy. (2003). A critical companion to Beowulf. Cambridge: D.S Brewer.

Remmers, A. (1993). Wörterbuch der ausgestorbenen ostfriesichen Dialekte (Harlinger, Wangerooger, Brokmerländer und Würster Ostfriesisch). Schwelm: Manuskript.

Riecke, J. (1996). Die schwachen jan-Verben des althochdeutschen: Ein Gliederungsversuch. (= Studien zum Althochdeutschen 32). Göttingen: Vandenhoeck \& Ruprecht.

Ringe, D. R. (1984). Germanic " $\bar{e} 2$ " and *r. Die Sprache, 30, 138-155.

Robinson, F. C. (1970). Lexicography and literary criticism: A caveat. In J. L. Rosier (Ed.), Philological essays: Studies in Old and Middle English language and literature in honour of Herbert Dean Meritt (pp. 99-110). The Hague: Mouton. (Reprinted in Robinson 1993: 140-52).

Robinson, F. C. (1993). The tomb of Beowulf and other essays on Old English. Cambridge, MA-Oxford: Blackwell.

Schützeichel, R. (2006). Althochdeutsches Wörterbuch (6th ed.). Tübingen: Niemeyer.

Stellmacher, D. et al. (1965-). Niedersächsisches Wörterbuch. Neumünster: Wachholtz.

Stiles, P. V. (2004). Consumer issues: Beowulf 3115a and Germanic "bison"”. In J. H. W. Penney (Ed.), Perspectives on Indo-European studies in honour of Anna Morpurgo Davies (pp. 461-473). Oxford: University Press.

Publisher's Note Springer Nature remains neutral with regard to jurisdictional claims in published maps and institutional affiliations. 